\title{
Citizen Science Collaboration with the U.S. Geological Survey in Alaska
}

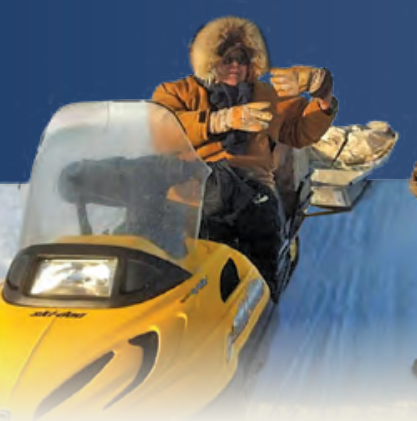

Citizen science is science undertaken by the public, usually in collaboration with professional scientific institutions. It encourages citizens to tackle real-world scientific problems and augments traditional science by expanding the coverage of data collection and by reducing costs of fieldwork in remote locations. Information collected by volunteers enables us all to gain a deeper understanding of how the natural world works and how it is changing. The U.S. Geological Survey (USGS) is a leading Federal agency in fostering citizen-science collaborations, and the examples in this publication show the value of those collaborations.

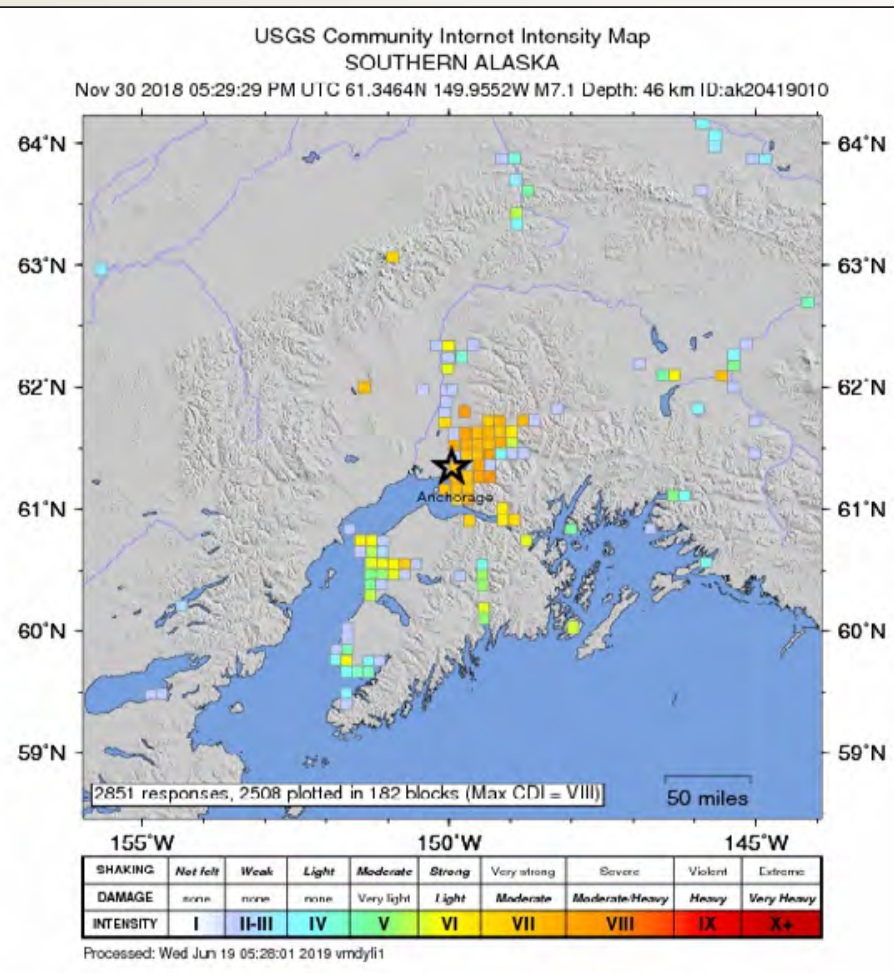

Screen shot of a Did You Feel It? map of a magnitude 7.1 earthquake that occurred in Anchorage, Alaska, on November 30, 2018. [Nearly 3,000 citizen-scientists contributed to the map.]

\section{Natural Hazard Response}

Did You Feel It? This app collects information from people who felt earthquakes and converts it into a real-time map that helps the public and emergency responders better understand the effects of earthquakes. It provides data in areas where there are no seismic instruments and helps constrain instrumental data used for ShakeMap and PAGER alerts. ShakeMaps are near-realtime maps of ground motion and shaking intensity from seismic networks, while PAGER alerts provide estimates of potential fatalities and economic loss following an earthquake on a global scale.
Citizen Network Ash Collection and Observation Program: The Alaska Volcano Observatory (AVO) developed this program so that Alaskans can report observations of volcanic ash. The reports are shared with the National Weather Service to track where ash plumes are headed and to guide advisories about ash falling onto the landscape.

Citizens can also collect ash samples and send them to AVO. With this help from community members, volcano scientists can greatly expand their sampling of ash deposits.

\section{Geospatial Mapping}

The National Map Corps: This is a crowd-sourced mapping app that allows for input about details of built structures. The app allows volunteers to edit structures in all 50 States, Puerto Rico, and the U.S. Virgin Islands. By updating and verifying structural data, volunteers are making significant contributions to the USGS National Structures Database, the National Map, and U.S. Topo Maps!

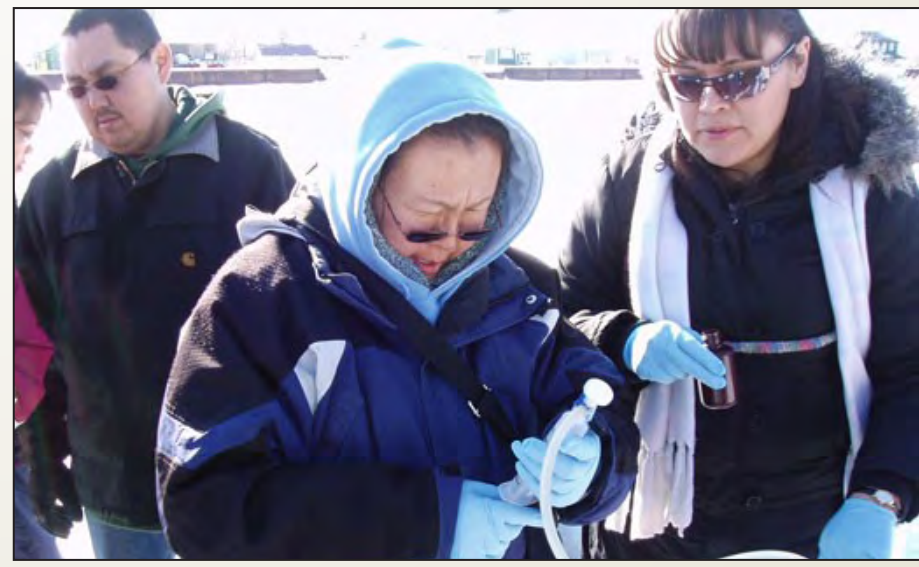

Water technicians sample carbon dioxide from the Tanana River, Alaska, March 2007. [Indigenous Observation Network program. Photograph by U.S. Geological Survey, public domain.] 


\section{Water Quality and Streamflow}

The Indigenous Observation Network (ION): This is a communitybased project initiated by the Yukon River Inter-Tribal Watershed Council and the USGS. By using existing USGS research infrastructure and supplementing USGS data, ION investigates changes in surfacewater geochemistry and permafrost dynamics throughout the Yukon River Basin. More than 300 trained Indigenous Yukon River Basin citizens collect water-quality samples and active layer data such as maximum thaw depth, soil temperature, and moisture. These data assist global efforts to characterize Arctic river fluxes and their relationship to the carbon cycle, weathering, and permafrost degradation.

The Strategic Needs of Water on the Yukon (SNOWY):

This project involves scientists from

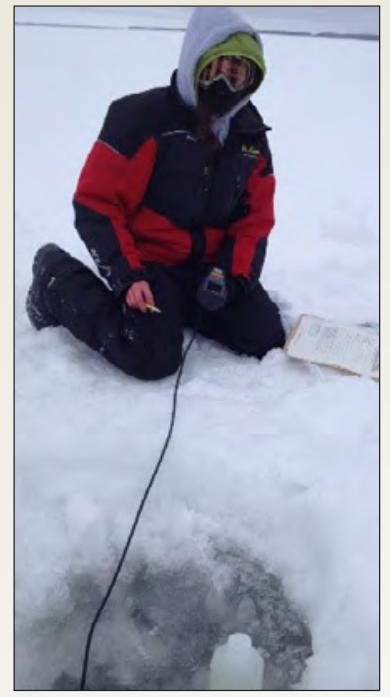

Carol Hasburgh (former Yukon River Inter-Tribal Watershed Council employee) taking a River Basin, Alaska. [Strategic Needs of Water on the Yukon project. Photograph by Ryan Toohey, U.S. Geological Survey.] water sample from the Yukon multiple disciplines, government agencies, non-profit organizations, universities, and Lower Yukon River Basin and Yukon-Kuskokwim Delta communities to study the effects of climate change. It focuses on collecting regional snow, ice, and water data. The goal is to capture the story of environmental change in this region.

Continuous Monitoring and Baseline Assessment of Water Quality of Transboundary Alaskan Rivers: The quantity and quality of streamflow in transboundary watersheds of southeast Alaska is important to many people, and development and operation of several mines in Canada has increased the interest in current and future conditions in these watersheds. The USGS is partnering with local Tribes and other Federal agencies to assess the geology and mineralization potential of study area watersheds, to collect data to characterize the water, sediment, and biological quality of the rivers, and to establish partnerships. The resulting information will help predict changes in waterquality resulting from future mining activities.

\section{Wildlife, Fish, and Habitat}

Local Environmental Observer Network (LEO): Initiated by the Environmental Protection Agency and the Alaska Native Tribal Health Consortium, this program helps citizens share environmental observations and to find explanations for environmental events. Citizens can engage experts in many different organizations, including the USGS.

Looking Forward, Looking Back-Building Resilience Today: This program builds resilience to environmental events by engaging Tribal leaderships and environmental staff. The series builds upon Indigenous knowledge and focuses on understanding changes to Tribal lands, learning about planning tools and resources, and documenting Indigenous knowledge.
Yukon-Kuskokwim Delta Berry Outlook: Co-Producing Knowledge to Better Understand Changing Resources: This project helps understand changing berry resources in the Yukon-Kuskokwim Delta (YKD). Berries are an important food for Alaska Natives and for the large migratory bird population of the YKD. The USGS partnered with Tribal Councils in four YKD communities to document local knowledge of berry abundance and distribution, helping ecological modeling and the forecasting of potential berry responses to future climate scenarios.

Bringing Scientists and Stakeholders Together through ScienceTapes (ScienceTapes): This project improves communication between scientists and stakeholders by recording stories of collaborations that improved the understanding of Alaska's landscapes. ScienceTapes has recorded conversations with scientists, students, resource managers, community members, politicians, Alaskan elders, and media personnel. The conversations are archived with StoryCorps and the American Folklife Center at the Library of Congress in Washington, D.C.

Climate Impacts on Alaskan and Yukon Rivers, Fish, and Communities as Told through Co-Produced Scenarios: The effects of Arctic warming are uncertain. Improved understanding of ongoing changes requires close partnership among Native groups and researchers. This project advances the understanding of hydrologic change and its potential impacts on the Arctic by facilitating Indigenous community-based monitoring of rivers, engagement and oversight, ethnographic methods, and computer simulations.

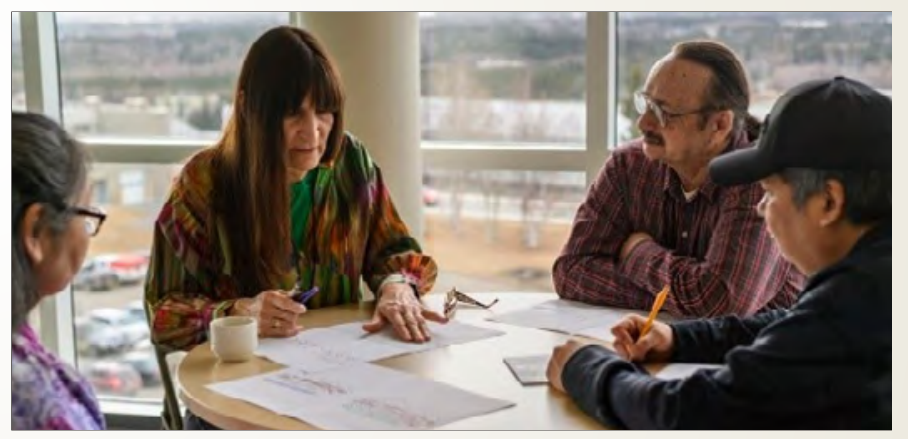

Tribal liaison Malinda Chase works with community members on a climatechange visualization. [Looking Forward, Looking Back: Building Resilience Today project. Photograph by Molly Tankersly, U.S. Geological Survey.]

Banner Photograph: Collecting water quality information on the Tanana River. Photograph by Ryan Toohey, USGS Alaska Climate Adaptation Science Center.

Some of the programs mentioned in this report can be accessed at the websites noted below.

Did You Feel It?: https://earthquake.usgs.gov/data/dyfi/ PAGER: https://earthquake.usgs.gov/data/pager/

ShakeMap: https://earthquake.usgs.gov/data/shakemap/

The Indigenous Observation Network: https:/www.usgs.gov/centers/ casc-sc/science/yukon-river-basin-indigenous-observation-network U.S. Topo Maps: https://nationalmap.gov/ustopo/index.html

By Elizabeth Powers and Dee Williams.

For more information, contact:

Science Coordinator, Alaska Science Center, U.S. Geological Survey, 4210 University Drive Anchorage, Alaska, 99508 